\title{
The relationship between severity of gastric inflammation due to Helicobacter pylori and colorectal malignancies
}

\section{Helikobakter pilloriye bağlı gastrik inflamasyon şiddetinin kolorektal malignansilerle ilişkisi}

\section{Oktay Bulur ${ }^{1}$, Evrim Kahramanoğlu Aksoy², Güllçin Şimşek ${ }^{3}$, Murat Eser ${ }^{4}$, Zeliha Asiltürk ${ }^{4}$, Kursat $\mathrm{Dal}^{4}$, Metin Uzman ${ }^{2}$}

${ }^{\text {IC }}$ umhuriyet University, School of Medicine, Department of Gastroenterology. Sivas, Turkey

${ }^{2}$ University of Health Sciences Kecioren Teaching and Research Hospital, Department of Gastroenterology. Ankara, Turkey

${ }^{3}$ University of Health Sciences Kecioren Teaching and Research Hospital, Department of Pathology. Ankara, Turkey

${ }^{4}$ University of Health Sciences Kecioren Teaching and Research Hospital, Department of Internal Medicine. Ankara, Turkey

Corresponding author: Oktay Bulur, MD, Cumhuriyet University, School of Medicine, Department of Gastroenterology. Sivas, Turkey

E-mail: oktaybulur34@gmail.com

Received/Accepted: August 10, 2021 /December 08, 2021

Conflict of interest: There is not a conflict of interest.

\section{SUMMARY}

Objective: Several factors play role in colorectal carcinogenesis. Among these factors, helicobacter pylori infection is supposed to be one of the causative factors. Previous studies were focused on investigation of the relationship between helicobacter pylori existence and colon carcinomas by particular serological diagnostic tests. The aim of our study was to determine the effect of the helicobacter pylori infection and the severity of inflammation related to this infection on the colon carcinomas and non carcinoma colon mass lesions(tubular adenoma, tubulovillous adenoma, hyperplastic polyp).

Method: A retrospective study was conducted at Kecioren Teaching Research Hospital between 2010 to 2018. The files of 657 patients who underwent colonoscopy and were diagnosed as colon benign or malign mass lesions were examined retrospectively from the hospital database. Two hundred five patients who had undergone both upper gastrointestinal endoscopy and colonoscopies were included in the study. The presence and severity of inflammation due to helicobacter pylori were evaluated by histopathological examination of biopsies taken during upper gastrointestinal endoscopy. The severity of $\mathrm{H}$. pylori inflammation was graded according to the Sydney classification

Results: In the comparison of colon carcinoma with other colon mass lesions group, there was no statistical significance in terms of gender $(\mathrm{P}=$ 0.094) and $\mathrm{H}$. pylori serology $(\mathrm{P}=0.998)$. However, the degree of inflammation was significantly high in patients with colon carcinoma than other colon mass lesions $(\mathrm{P}<0.001)$.

Conclusions: The fact that the severity of helicobacter pylori inflammation is higher in patients with colon carcinoma than patients with non-carcinoma colonic mass lesions suggests that inflammation due to helicobacter pylori may be more important than the presence of helicobacter pylori in the carcinogenesis of colon cancer.

Keywords: Helicobacter pylori, colon carcinoma , inflammation

(D) Oktay Bulur
(D) Evrim Kahramanoğlu Aksoy
(iD) Gülçin Şimşek
(iD Murat Eser
(D) Zeliha Asiltürk
(D) Kursat Dal
(D) Metin Uzman

ORCID IDs of the authors: O.B. 0000-0002-0332-3871 E.K.A. 0000-0001-8887-3428 G.Ş. 0000-0001-7710-4631 M.E. 0000-0002-6687-0899 Z.A. 0000-0003-1165-3982 K.D. 0000-0002-9116-6115 M.U. 0000-0002-5412-8523 
ÖZET

Amaç: Kolorektal karsinom gelişiminde çeşitli faktörler rol oynamaktadır. Helikobakter pilori infeksiyonu bu faktörlerden biri olarak öne sürülmektedir. Önceki çalışmalar, serolojik tanı testleri ile belirlenen helikobakter pilori varlığının kolorektal karsinom ile ilişkisinin araştırılmasına odaklanmıştır. Önceki çalışmalardan farklı olarak çalışmamızın amacı, helikobakter pilori infeksiyonu ve buna bağlı inflamasyon şiddetinin kolorektal karsinom ve karsinom dışı kolon kitle lezyonları üzerindeki etkisini belirlemektir.

Yöntem: Bu retrospektif çalışma 2010-2018 yılları arasında, Keçiören Eğitim Araştırma Hastanesi gastroenteroloji kliniğine başvuran ve yapılan kolonoskopi sonucunda benign veya malign lezyon saptanan 657 hastanın dosyalarının geriye yönelik taranması ile yapılmıştır. Kolonoskopi işlemi ile birlikte üst gastrointestinal sistem endoskopisi işlemi yapılmış ve helikobakter pilori seropozitifliği olan 205 hasta çalışmaya dahil edilmiştir. Helikobakter pilori varlığı ve inflamasyon şiddeti üst gastrointestinal sistem endoskopisi sırasında alınan biyopsilerin histopatolojik incelemesi sonucu belirlenmiştir. Helikobakter pilori inflamasyon şiddeti Sydney sınıflamasına gore yapılmıştır.

Bulgular: Kolon karsinomu olan hasta grubu ile kolonun karsinom dışı kitle lezyonlarına sahip hastaların karşılaştırması yapıldığında her iki grup arasında cinsiyet $(\mathrm{P}=0.094)$ ve helikobakter pilori serolojisi $(\mathrm{P}=0.998)$. arasında istatistiksel fark yoktu. Bununla birlikte helikobakter pilori inflamasyonunun şiddeti kolon karsinomlu hastalarda, karsinom dışı kolon kitle lezyonu olan hastalara göre anlamlı derecede yüksek saptandı $(\mathrm{P}<0.001)$.

Sonuç: Kolon karsinomu olan hastalarda helikobakter pilori inflamasyon şiddetinin karsinom dışı kolon kitle lezyonlarından daha yüksek bulunması kolon kanseri karsinogenezinde helikobakter pilori varlığından ziyade helikobakter piloriye bağlı oluşan inflamasyonun daha önemli olabileceğini düşündürmektedir.

Anahtar sözcükler: Helikobakter pilori, kolon kanseri, inflamasyon

\section{INTRODUCTION}

There is an association between helicobacter pylori (H. pylori) infection and malignancies. Although carcinogenesis and pathogenesis in $H$. pylori infection are not fully understood, several mechanisms such as chronic inflammation, genetic mutations, and virulence factors are proposed to explain the role of $H$. pylori in different carcinomas 1. Gastric carcinoma is the most common cancer associated with H. pylori $^{2}$. H. pylori is also related to mucosa-associated lymphomas (MALT lymphomas), pancreatic cancer, and biliary tract cancers. $^{3-5}$

Colorectal cancer (CRC) ranks third in the ranking of cancers and second in the ranking of cancerrelated mortalities in both sexes and all ages worldwide. ${ }^{6}$ Among different etiologies in CRC carcinogenesis, epidemiological analyses have shown a relationship between colorectal adenomas and/or adenocarcinomas with H. pylori ${ }^{7,8}$

Studies conducted to date have investigated this relationship on the basis of $H$. pylori existence with particular serological diagnostic tests.

Unlike other studies, the aim of our study was to determine the effect of the helicobacter pylori infection and the severity of inflammation related to this infection on the colon carcinomas and mass lesions of colon other than carcinomas.

\section{MATERIAL AND METHODS}

This retrospective study was conducted at Kecioren Teaching and Research hospital's Department of Internal Medicine. Between 2010 to 2018, the files of 657 patients, who underwent colonoscopy and were diagnosed with colon benign or malign lesions, were examined retrospectively from the hospital database. A total of 205 patients who underwent both upper gastrointestinal endoscopy and colonoscopy were analyzed. The colonic lesions that were diagnosed histopathologically were classified as carcinoma and mass lesions other than carcinoma. The presence and the severity of inflammation due to $H$. pylori were evaluated by histopathological examination of biopsies taken from at least two sites including antrum and corpus at upper gastrointestinal endoscopy. Severity of $H$. pylori inflammation was graded according to the Sydney classification system. In 205 patients colon carcinoma and other colonic mass lesions were detected by pathologic assessment .Shapiro Wilk test, Mann Whitney U test, Kruskal Wallis and Dunn multiple comparison tests were used in the statistical comparisons. Chisquare test was applied in order to investigate the relationship between 2 categorical variables. Statistical analysis was performed with SPSS for Windows version 22.0 (IBM Corporation, United States ) and a $\mathrm{P}$ value $<0.05$ was accepted as statistically significant.

This study was conducted in accordance with the principles of the Declaration of Helsinki. The 
protocol of this study was reviewed and approved by the local ethics committee (Date: 26/09/2018, no: 1758). Written informed consent was obtained.

\section{RESULTS}

A total of 205 patients [87 (42.4\%) female; 118
(57.6\%) male] were included in the study. The average age of the patients was 68 years \pm standard deviation, SD (interquartile range, IQR: 59 78). Demographic data, presence of upper endoscopic evaluation and histopathological findings of patients are demonstrated in (Table 1).

Table 1: Characteristics of patients

\begin{tabular}{|c|c|c|c|}
\hline & & $\mathbf{n}$ & $\%$ \\
\hline \multirow[t]{2}{*}{ Gender } & Female & 261 & 39.70 \\
\hline & Male & 396 & 60.30 \\
\hline \multirow[t]{5}{*}{ Groups } & Colon carcinoma & 278 & 42.30 \\
\hline & $\begin{array}{l}\text { Non carcinoma colon mass } \\
\text { lesions }\end{array}$ & & \\
\hline & $\begin{array}{ll}\text { I. } & \text { Tubuler adenoma }\end{array}$ & 136 & 20.70 \\
\hline & $\begin{array}{l}\text { II. Tubulovillous } \\
\\
\text { adenoma }\end{array}$ & 37 & 5.60 \\
\hline & III. Hyperplastic polyp & 206 & 31.40 \\
\hline \multirow[t]{2}{*}{ Endoscopy } & Present & 205 & 31.20 \\
\hline & Absent & 452 & 68.80 \\
\hline \multirow[t]{2}{*}{ H pylori } & Positive & 104 & 50.70 \\
\hline & Negative & 101 & 49.30 \\
\hline
\end{tabular}

When colon carcinoma group was compared with non carcinoma colon mass lesions group (tubular adenoma, tubulovillous adenoma, hyperplastic polyp), there was no statistical significance in terms of gender $(\mathrm{P}=0.094)$, family history of colorectal carcinoma $(\mathrm{P}>0.05)$ and $H$. pylori presence $(\mathrm{P}=0.998)$. However, there was statistically significant difference in termes of smoking status $(\mathrm{P}<0.05)$, alcohol consumption $(\mathrm{P}<0.05), \mathrm{BMI}$ (body mass index $)(\mathrm{P}<0.05)$ and age $(\mathrm{P}<0.001)$ between colon carcinoma and non carcinoma colon mass lesions. Additionally intense of inflammation was significantly higher in patients with colon carcinoma than non carcinoma colon mass lesions $(\mathrm{P}<0.001)$, Table 2. 
Table 2 : Comparison of groups according to gender, H pylori presence, and inflammation grade

\begin{tabular}{|c|c|c|c|}
\hline Variable & Colorectal cancer & $\begin{array}{l}\text { Non carcinoma } \\
\text { colon mass lesions }\end{array}$ & $\mathbf{P}$ \\
\hline $\operatorname{Age}(\operatorname{mean} \pm$ SD $)$ & $67,13 \pm 14,16$ & $57,82 \pm 13,57$ & 0.001 \\
\hline \multicolumn{4}{|l|}{ Gender } \\
\hline Female (n) & 53 & 34 & 0,094 \\
\hline Male (n) & 85 & 33 & \\
\hline \multicolumn{4}{|l|}{$\underline{\text { H pylori }}$} \\
\hline H pylori $(+)(\mathrm{n})$ & 70 & 34 & \multirow{2}{*}{0,998} \\
\hline H pylori $(-)(\mathrm{n})$ & 68 & 33 & \\
\hline \multicolumn{4}{|l|}{$\underline{\text { H pylori İnflammation }}$} \\
\hline Grade 1(n) & 36 & 32 & \multirow{3}{*}{0,001} \\
\hline Grade 2(n) & 22 & 1 & \\
\hline Grade 3(n) & 11 & 2 & \\
\hline \multicolumn{3}{|l|}{ Smoking status } & \multirow{3}{*}{0.024} \\
\hline Smoker(n) & 36 & 23 & \\
\hline Non-Smoker (n) & 102 & 44 & \\
\hline BMI $(\operatorname{mean} \pm \mathrm{SD})\left(\mathrm{kg} / \mathrm{m}^{2}\right)$ & $26,056 \pm \mathbf{2 , 8 6}$ & $24,775 \pm \mathbf{2 , 8 6}$ & 0.003 \\
\hline \multicolumn{3}{|l|}{ AlcoholConsumption } & \multirow{3}{*}{0.024} \\
\hline Current/Ex-drinker(n) & 4 & 7 & \\
\hline No(n) & 134 & 60 & \\
\hline \multicolumn{3}{|l|}{$\begin{array}{l}\text { Family History of } \\
\text { Colorectal carcinoma }\end{array}$} & \multirow{3}{*}{0.638} \\
\hline Yes(n) & 6 & 2 & \\
\hline No(n) & 132 & 65 & \\
\hline
\end{tabular}




\section{DISCUSSION}

In our study, there was no statistical significance between colon carcinoma and non carcinoma colon mass lesions group in terms of gender and $\mathrm{H}$. pylori presence . However, the degree of inflammation was significantly correlated with colon carcinoma and non carcinoma colon mass lesions.

Several factors may take part in the carcinogenesis of colon malignancies.These factors are alcohol, cigarette, increased body mass index, processed meat,microbial dysbiosis, low fiber diet, inflammatory bowel disease, diabetes mellitus and genetic alterations ${ }^{7,9}$

Gut microbiota normally consists of several beneficial bacteria types such as Lactobacillus, Bifidobacterium, Clostridium spp. and Streptococcus mutants which make a barrier over colon epithelium against cellular injury ${ }^{10}$. A variety of disorders such as inflammatory bowel disease, obesity, and diabetes decrease the beneficial bacteria colonization and increase the colonization of harmful bacteria in colon ${ }^{11,12}$.This shift is termed dysbiosis. Escherichia coli, Bacteroides fragilis, Fusobacterium spp., and Peptostreptococcus spp. are the most colonized bacteria species in dysbiosis ${ }^{13}$.

As a result of the increased harmful bacteria species in the colon epithelium, the epithelium loses its protective barrier. Increased endotoxins, oxidants and inflammation cause DNA damage and cellular damage in the colon epithelium. ${ }^{14}$ This micro-environment contributes to carcinogenesis in colon epithelium. ${ }^{15,16}$ Several mechanisms were proposed to elucidate the relationship between dysbiosis and carcinogenesis. These mechanisms include:

Chronic inflammation:Chronic inflammation occurs in colon epithelium as a consequence of dysbiosis. Chronic inflammation is one of the initiative factors in colorectal carcinogenesis 17 . Increased levels of cytokines, pro-inflammatory interleukins (IL-1-6-7-22) and TNF-alfa are associated with uncontrolled chronic inflammation. ${ }^{18,19}$

Chronic inflammatory activity triggers a cascade that includes several growth factors and cytokines that disrupt apoptosis,increased oxidative stress, proliferation and angiogenesis. ${ }^{20}$

Other mechanisms include the activation of MSI (microsatellite instability gene) and CIMP (CpG island methylator phenotype) by fusobacterium nucleatum. Additionally,fusobacterium interacts with E-cadherin and stimulates malign transformation of the epithelial cells. ${ }^{21}$ Furthermore, enterotoxin of Bacteroides fragilis leads to carcinogenesis by activating the Wnt/ $\beta$ catenin and nuclear factor- $\kappa \mathrm{B}$. Bacterial toxins affect cell cycle by damaging DNA. ${ }^{22}$ Dysbiosis also raises gut microbial metabolites ( secondary bile acid, glucuronic acid, and acetaldehyde) that cause epithelial cell injury. ${ }^{23}$

Besides Escherichia coli, bacteroides fragilis, and fusobacterium,H.pylori arealso implicated in colorectal carcinogenesis. ${ }^{24}$ Studies conducted to date have investigated the relationship between $H$. pylori and colon carcinomas and colon adenomas on the basis of $H$. pylori serology. Unlike these studies, in our study, the intensity of H.pylori colonization and the grade of inflammation due to H. Pylori infection were found to be significantly associated with colorectal cancer and other colon lesions.

The pathophysiologic mechanisms underlying the association between $H$. pylori infection and colorectal neoplasms are not clear. Several mechanisms have been proposed to explain $H$ pylori and colon carcinogenesis ${ }^{25}$.

It is suggested that the primary mechanism for $H$. pylori and colon carcinoma relation is probably the activation of the inflammatory response of the gastric cells. ${ }^{25}$, 26 Gastric body mucosal inflammation increases serum gastrin levels, and increased gastrin promotes carcinogenesis through its trophic effects. ${ }^{27}$ Our findings support this hypothesis. It is assumed that gastrin makes this effect possible via receptors that are unique to the gastrin (gastrin/cholecystokinin-type B receptor (CCKB-R) ${ }^{28}$ Despite this conclusion, Selgrad et al. $^{29}$ found that not high gastrin levels but cytotoxin-associated gene (Cag) presence is associated with increased risk of colorectal cancer. Papastergiou et al. ${ }^{30}$ concluded that the mechanism behind the $H$. pylori-related carcinogenesis in colon carcinoma includes inflammatory process, changes in gut microflora and delivery of toxins and/or hormonal mediators. In addition, $H$. pylori urease enzyme can also turn gastric juice urea into ammonia and elevated high ammonia level in the lumen may promote cancer activity. ${ }^{31}$

Studies regarding the association of $H$. pylori with with colorectal cancer and/or colon polyps are controversial. Some studies found a significant relationship between $H$. pylori and colorectal cancer while others showed no such relationship. In our study, unlike other studies, we found that rather than $H$. pylori seropositivity, H. pylorirelated inflammation has a significant role in colon carcinogenesis. Abbass et al. ${ }^{32}$ demonstrated that 
there was no relation between colon malignancies and $H$. pylori. Soylu et al. ${ }^{33}$ found no statistically significant relationship between $H$. pylori and both colon polyp and polyp size. Similarly, Kalkan et al. ${ }^{34}$. observed no relationship between $H$. pylori seropositivity and colon polyps. Contrary to these findings, Nam et al. ${ }^{35}$ showed that there was a significant relationship between $H$. pylori presence and precancerous lesions of colon. Yang et al. ${ }^{36}$ concluded that $H$. pylori was linked with enhanced colon carcinoma hazard. In a nationwide population- based study, Liu et al. ${ }^{37}$ concluded that there was a statistically significant affiliation between $H$. pylori and both colorectal malignancies. In a study conducted by $\mathrm{Nam}$ et al. ${ }^{38}$, similar results were found showing that $H$. pylori were an independent risk factor for colorectal adenomas. Two meta-analysis conducted by Q. Wu et al. ${ }^{39}$ and F. Wang et al. ${ }^{40}$ from China showed a significant association between $H$. pylori and colonic neoplasia.

\section{CONCLUSION}

The fact that the severity of helicobacter pylori inflammation is higher in patients with colon carcinoma than patients with non-carcinoma colonic mass lesions suggests that inflammation due to helicobacter pylori may be more important than the presence of helicobacter pylori in the carcinogenesis of colon cancer.Our Study have some limitations. First this study is a retrospective study. We did not able to make a search about microbial dysbiosis and genetical alterations.

\section{Main Points:}

-The severity of gastric inflammation due to $\mathrm{H}$. pylori infection is important than $\mathrm{H}$. pylori seropositivity in colon carcinogenesis

- There was no significant difference in the presence of H.pylori infection between patients with colon cancer and patients with non carcinoma colon mass lesions

- The intensity of H.pylori inflammation was more prominent in patients with colon cancer than patients with non carcinoma colon mass lesions.

\section{DECLARATIONS:}

- Ethics approval and consent to participate: This research conducted in compatible to the Declaration of Helsinki, and was accepted by Health Sciences University Keçiören Teaching and Research Hospital ethics committee( date 26.09.2018) (no:092018/1758)

- Consent for publication: This manuscript does not contain any individual person's data in any form (including any individual details, images or videos)

- Availability of data and materials: The datasets generated and/or analysed during the current study are not publicly available.Before sharing the data set ,Ministry of Health should give permission but are available from the corresponding author on reasonable request.

- Competing interests: The authors declare that they have no competing interests

- $\quad$ Funding: There is no Funding in this study from any person, institute or company.

\section{REFERENCES}

1. Fu L, Xie C. A lucid review of Helicobacter pylori-induced DNA damage in gastric cancer. Helicobacter. 2019;24(5):e12631. doi: 10.1111/hel.12631. PubMed PMID: 31295756.

2. Jessurun J. Helicobacter pylori: an evolutionary perspective. Histopathology. 2021;78(1):39-47. doi: 10.1111/his.14245. PubMed PMID: 33382492 .

3. Juarez-Salcedo LM, Sokol L, Chavez JC, Dalia S. Primary Gastric Lymphoma, Epidemiology, Clinical Diagnosis, and Treatment. Cancer Control. 2018;25(1):1073274818778256. doi: 10.1177/1073274818778256. PubMed PMID: 29779412; PubMed Central PMCID: PMCPMC6028178.

4. Guo Y, Liu W, Wu J. Helicobacter pylori infection and pancreatic cancer risk: A metaanalysis. J Cancer Res Ther. 2016;12(Supplement):C229-C32. doi: 10.4103/0973-1482.200744. PubMed PMID: 28230023.

5. Waluga M, Kukla M, Zorniak M, Bacik A, Kotulski R. From the stomach to other organs: Helicobacter pylori and the liver. World J Hepatol. 2015;7(18):2136-46. doi: 10.4254/wjh.v7.i18.2136. PubMed PMID: 26328025; PubMed Central PMCID: PMCPMC4550868.

\section{Globocan 2018. wwwuiccorg/new-global- cancer-data-globocan-2018. 2018.}

7. Wong MC, Ding H, Wang J, Chan PS, Huang J. Prevalence and risk factors of colorectal cancer in Asia. Intestinal research. 2019;17(3):317-29. doi: 10.5217/ir.2019.00021. PubMed PMID: 31085968; PubMed Central PMCID: PMC6667372.

8. Zuo Y, Jing Z, Bie M, Xu C, Hao X, Wang B. Association between Helicobacter pylori infection and the risk of colorectal cancer: A systematic 
review and meta-analysis. Medicine. 2020;99(37):e21832. doi: 10.1097/MD.0000000000021832. PubMed PMID: 32925719; PubMed Central PMCID: PMC7489651.

9. Bresalier RS. ColorectalCancer. Sleisenger and Fordtran's Gastrointestinal and Liver Disease,Elsevier. 15th June 2020 2(ColorectalCancer):2108-52.

10. Liu X, Cheng Y, Shao L, Ling Z. Alterations of the Predominant Fecal Microbiota and Disruption of the Gut Mucosal Barrier in Patients with EarlyStage Colorectal Cancer. BioMed research international. 2020;2020:2948282. doi: 10.1155/2020/2948282. PubMed PMID: 32280686; PubMed Central PMCID: PMC7114766 commercial or financial relationships that could be construed as a potential conflict of interest.

11. Wu Y, Shi L, Li Q, Wu J, Peng W, Li H, et al. Microbiota Diversity in Human Colorectal Cancer Tissues Is Associated with Clinicopathological Features. Nutrition and cancer. 2019;71(2):214-22. doi: 10.1080/01635581.2019.1578394. PubMed PMID: 30843732.

12. Tozun N, Vardareli E. Gut Microbiome and Gastrointestinal Cancer: Les liaisons Dangereuses. J Clin Gastroenterol. 2016;50 Suppl 2, Proceedings from the 8th Probiotics, Prebiotics \& New Foods for Microbiota and Human Health meeting held in Rome, Italy on September 13-15, 2015:S191-S6. doi: 10.1097/MCG.0000000000000714. PubMed PMID: 27741173.

13. Gao R, Kong C, Li H, Huang L, Qu X, Qin N, et al. Dysbiosis signature of mycobiota in colon polyp and colorectal cancer. European journal of clinical microbiology \& infectious diseases : official publication of the European Society of Clinical Microbiology. 2017;36(12):2457-68. doi: 10.1007/s10096-017-3085-6. PubMed PMID: 28821976.

14. Mori G, Rampelli S, Orena BS, Rengucci C, De Maio G, Barbieri G, et al. Shifts of Faecal Microbiota During Sporadic Colorectal Carcinogenesis. Scientific reports. 2018;8(1):10329. doi: 10.1038/s41598-01828671-9. PubMed PMID: 29985435; PubMed Central PMCID: PMC6037773.

15. Shiotani A, Fukushima S, Matsumoto $H$. [Carcinogenesis and Gut Microbiota]. Gan to kagaku ryoho Cancer \& chemotherapy. 2019;46(2):199-204. PubMed PMID: 30914517.

16. de Waal GM, de Villiers WJS, Forgan T, Roberts T, Pretorius E. Colorectal cancer is associated with increased circulating lipopolysaccharide, inflammation and hypercoagulability. Scientific reports. 2020;10(1):8777. doi: 10.1038/s41598-02065324-2. PubMed PMID: 32472080; PubMed Central PMCID: PMC7260372.

17. Belayneh YM, Amare GG, Meharie BG. Updates on the molecular mechanisms of aspirin in the prevention of colorectal cancer: Review. Journal of oncology pharmacy practice : official publication of the International Society of Oncology Pharmacy Practitioners. 2021:1078155220984846. doi: 10.1177/1078155220984846. PubMed PMID: 33427041 .

18. Chang SC, Yang WV. Hyperglycemia, tumorigenesis, and chronic inflammation. Critical reviews in oncology/hematology. 2016;108:14653. doi: 10.1016/j.critrevonc.2016.11.003. PubMed PMID: 27931833.

19. Dmitrieva-Posocco O, Dzutsev A, Posocco DF, Hou V, Yuan W, Thovarai V, et al. Cell-TypeSpecific Responses to Interleukin-1 Control Microbial Invasion and Tumor-Elicited Inflammation in Colorectal Cancer. Immunity. 2019;50(1):166-80 e7. doi: 10.1016/j.immuni.2018.11.015. PubMed PMID: 30650375; PubMed Central PMCID: PMC6490968.

20. Murata M. Inflammation and cancer. Environmental health and preventive medicine. 2018;23(1):50. doi: 10.1186/s12199-018-0740-1. PubMed PMID: 30340457; PubMed Central PMCID: PMC6195709.

21. Lee DW, Han SW, Kang JK, Bae JM, Kim HP, Won JK, et al. Association Between Fusobacterium nucleatum, Pathway Mutation, and Patient Prognosis in Colorectal Cancer. Annals of surgical oncology. 2018;25(11):3389-95. doi: 10.1245/s10434-018-6681-5. PubMed PMID: 30062471 .

22. Tomkovich S, Yang Y, Winglee K, Gauthier J, Muhlbauer M, Sun X, et al. Locoregional Effects of Microbiota in a Preclinical Model of Colon Carcinogenesis. Cancer Res. 2017;77(10):262032. doi: 10.1158/0008-5472.CAN-16-3472. PubMed PMID: 28416491; PubMed Central PMCID: PMC5468752.

23. Lin C, Cai X, Zhang J, Wang W, Sheng Q, Hua $\mathrm{H}$, et al. Role of Gut Microbiota in the Development and Treatment of Colorectal Cancer. Digestion. 2019;100(1):72-8. doi: 10.1159/000494052. PubMed PMID: 30332668. 
24. Butt J, Epplein M. Helicobacter pylori and colorectal cancer-A bacterium going abroad? PLoS pathogens. 2019;15(8):e1007861. doi: 10.1371/journal.ppat.1007861. PubMed PMID: 31393968; PubMed Central PMCID: PMC6687094.

25. Kim TJ, Kim ER, Chang DK, Kim YH, Baek $\mathrm{SY}$, Kim K, et al. Helicobacter pylori infection is an independent risk factor of early and advanced colorectal neoplasm. Helicobacter. 2017;22(3). doi: 10.1111/hel.12377. PubMed PMID: 28124492.

26. Wang M, Kong WJ, Zhang JZ, Lu JJ, Hui WJ, Liu WD, et al. Association of Helicobacter pylori infection with colorectal polyps and malignancy in China. World journal of gastrointestinal oncology. 2020;12(5):582-91. doi: 10.4251/wjgo.v12.i5.582. PubMed PMID: 32461789; PubMed Central PMCID: PMC7235179.

27. Gunawardhana N, Jang S, Choi YH, Hong YA, Jeon YE, Kim A, et al. Helicobacter pylori-Induced HB-EGF Upregulates Gastrin Expression via the EGF Receptor, C-Raf, Mek1, and Erk2 in the MAPK Pathway. Frontiers in cellular and infection microbiology. 2017;7:541. doi: 10.3389/fcimb.2017.00541. PubMed PMID: 29379775; PubMed Central PMCID: PMC5775237.

28. Luan C, Liu Z, Li Y, Dong T. Association among helicobacter pylori infection, gastrin level and colorectal cancer in patients aged 50 years and over. Pakistan journal of medical sciences. 2020;36(5):899-903. doi: 10.12669/pjms.36.5.1993. PubMed PMID: 32704260; PubMed Central PMCID: PMC7372695.

29. Selgrad M, Bornschein J, Kandulski A, Hille C, Weigt J, Roessner A, et al. Helicobacter pylori but not gastrin is associated with the development of colonic neoplasms. International journal of cancer. 2014;135(5):1127-31. doi: 10.1002/ijc.28758. PubMed PMID: 24496701.

30. Papastergiou V, Karatapanis S, Georgopoulos SD. Helicobacter pylori and colorectal neoplasia: Is there a causal link? World J Gastroenterol. 2016;22(2):649-58. doi: 10.3748/wjg.v22.i2.649. PubMed PMID: 26811614; PubMed Central PMCID: PMC4716066.

31. Kumar A, Kim M, Lukin DJ. Helicobacter pylori is associated with increased risk of serrated colonic polyps: Analysis of serrated polyp risk factors. Indian journal of gastroenterology : official journal of the Indian Society of Gastroenterology.
2018;37(3):235-42. doi: 10.1007/s12664-0180855-8. PubMed PMID: 29876742.

32. Abbass K, Gul W, Beck G, Markert R, Akram S. Association of Helicobacter pylori infection with the development of colorectal polyps and colorectal carcinoma. South Med J. 2011;104(7):473-6. doi: 10.1097/SMJ.0b013e31821 e9009. PubMed PMID: 21886044.

33. Soylu A, Ozkara S, Alis H, Dolay K, Kalayci $\mathrm{M}$, Yasar N, et al. Immunohistochemical testing for Helicobacter Pylori existence in neoplasms of the colon. BMC Gastroenterol. 2008;8:35. doi: 10.1186/1471-230X-8-35. PubMed PMID: 18702825; PubMed Central PMCID: PMCPMC2527302.

34. İsmail Hakk1 KALKAN FS, Sefa GÜLİTER, Pinar ATASOY. The relationship between gastric preneoplastic findings and colon polyps Akademik gastroenteroloji dergisi. 2013;12(3):108-12.

35. Nam JH, Hong CW, Kim BC, Shin A, Ryu KH, Park BJ, et al. Helicobacter pylori infection is an independent risk factor for colonic adenomatous neoplasms. Cancer causes \& control : CCC. 2017;28(2):107-15. doi: 10.1007/s10552-0160839-x. PubMed PMID: 28025763.

36. Yang F, Xu YL, Zhu RF. Helicobacter pylori infection and the risk of colorectal carcinoma: a systematic review and meta-analysis. Minerva medica. 2019;110(5):464-70. doi: 10.23736/S0026-4806.19.05942-1. PubMed PMID: 31368293.

37. Liu IL, Tsai CH, Hsu CH, Hu JM, Chen YC, Tian YF, et al. Helicobacter pylori infection and the risk of colorectal cancer: a nationwide populationbased cohort study. QJM : monthly journal of the Association of Physicians. 2019;112(10):787-92. doi: 10.1093/qjmed/hcz157. PubMed PMID: 31250012 .

38. Nam SY, Park BJ, Ryu KH, Nam JH. Effect of Helicobacter pylori infection and its eradication on the fate of gastric polyps. Eur J Gastroenterol Hepatol. 2016;28(4):449-54. doi: 10.1097/MEG.0000000000000553. PubMed PMID: 26735158.

39. Wu Q YZ, Xu P, Gao LC, Fan DM. Association between Helicobacter pylori infection and the riskof colorectal neoplasia: a systematic review and meta-analysis . Colorectal Disease 2013;July(7):e352-64.

40. Wang F, Sun MY, Shi SL, Lv ZS. Helicobacter pylori infection and normal colorectal mucosaadenomatous polyp-adenocarcinoma sequence: a 
meta-analysis of 27 case-control studies.

Colorectal Dis. 2014;16(4):246-52. doi:

10.1111/codi.12290. PubMed PMID: 23692360. 